\title{
Research Article: Economics of chilli processing in southern districts of Tamil Nadu
}

Article Chronicle : Received : 17.07.2017;

Accepted :

01.08 .2017
Author for correspondence :

\section{K. DIVYA}

Department of Agricultural and Rural Management, Tamil Nadu Agricultural

University, COIMBATORE (T.N.) INDIA

\section{K. DIVYA, M. KAVITHA, V. SARAVANAKUMAR AND K. MALARKODI}

SUMMARY : The study was conducted in Ramanathapuram, Thoothukudi and Virudhunagar districts of Tamil Nadu state. In total, 10 processing units were selected randomly and interviewed for the study. The recovery of large processing units $(92.37 \%)$ was more than medium $(90.49 \%)$ and small units $(87.86$ $\%)$. Margin of processors increases with the increase in the size of processing unit. All the processing units were operating above the break even quantity in the study area.

How to cite this article : Divya, K., Kavitha, M., Saravanakumar, V. and Malarkodi, K. (2017). Economics of chilli processing in southern districts of Tamil Nadu. Agric. Update, 12(TECHSEAR-6) : 1563-1566; DOI: 10.15740/HAS/AU/12. TECHSEAR(6)2017/1563-1566.

KEY WoRDS:

Chilli processing,

Recovery, Capacity,

Fiexed cost,

Variable cost 